\title{
Akouédo, The Landfill Overexploited and Dangerous of Abidjan District (Ivory Coast)
}

\author{
YAO-KOUASSI Quonan Christian ${ }^{1}$, GOHOUROU Florent ${ }^{2}$ \\ University Jean Lorougnon Guédé, (Daloa, Ivory Coast)
}

\begin{abstract}
The population explosion coupled with the socio-political crisis accentuates the difficulties of the district authorities in Abidjan to set up infrastructure and efficient services for the management of domestic, hospital and industrial waste. The majority of this waste is directly found on sidewalks district or the Akouédo landfill which remains the unique legal tank. As a result, our study intends to analyze and assess the effectiveness and impact of the Akouedo landfill on the riparian population. To this end, we conducted an hybrid investigation with direct observation of the study area followed of a field survey with a population of 876 people living in the village of Akouedo. This work showed from the Akouédo landfill is saturated with the presence of heavy metals. On the other hand, it has environmental and health impacts on local communities and the nearby Ébrié lagoon.
\end{abstract}

Keywords: Akouedo landfill, Residents, Environmental Impact, Health Impact, Ébrié lagoon, District of Abidjan, Ivory Coast.

\section{Introduction}

The district of Abidjan, like the African capitals, is confronted with the rapid increase of its urban population, as well as the extension of the urban space resulting from an unstructured urbanization. With a population is of 4707 000 million (RGPH, 2014), Abidjan district seems more to be able to meet the ever-growing waste disposal. In this context, the waste themselves scattered in the city and in the unique Akouedo public landfill. This landfill which receives annually 550000 tonnes of waste, two thirds of which household waste a third of industrial waste and sometimes dangerous (Kouadio and al., 2000), today resembles a wild landfill. Indeed, she does no environmental standards and is outdated technically because its operating period is more than 30 years. Moreover, it has dangerous impacts in the short, medium and long term on the State of health of the people, land and resources. These different findings raise some questions: how the landfill is it managed? What treatments are waste upon arrival within the landfill? What impact it represents for the village population of Akouédo?

\section{Materials and Method}

The methodology used is based on a literature search and direct observation in the field which has allowed us to understand the local difficulties on the mode of operation of the landfill. As a result, we interviewed actors (responsible for health and safety in the district, grubbers). And finally, we conducted a descriptive sample random survey of 876 people whose average age was 23 years old with a female. The latter is important because it allows whether the pollution of the Akouedo dump had a direct impact on motherhood.

\subsection{Description of the Akouedo landfill}

The Akouédo landfill is located in peri-urban area in the town of Cocody, East of Abidjan district (map below), moving in the direction of Bingerville. It is installed near the village of Akouedo. This site is contaminated both by the uncontrolled waste pouring and the saturation of the landfill (Attahi, 2001). It's a thalweg branched of $2 \mathrm{~km}$ on a natural ravine with an area of 153 ha, 20 meters deep and $700 \mathrm{~m}$ wide; the current area exploited is estimated at about 20 hectares.

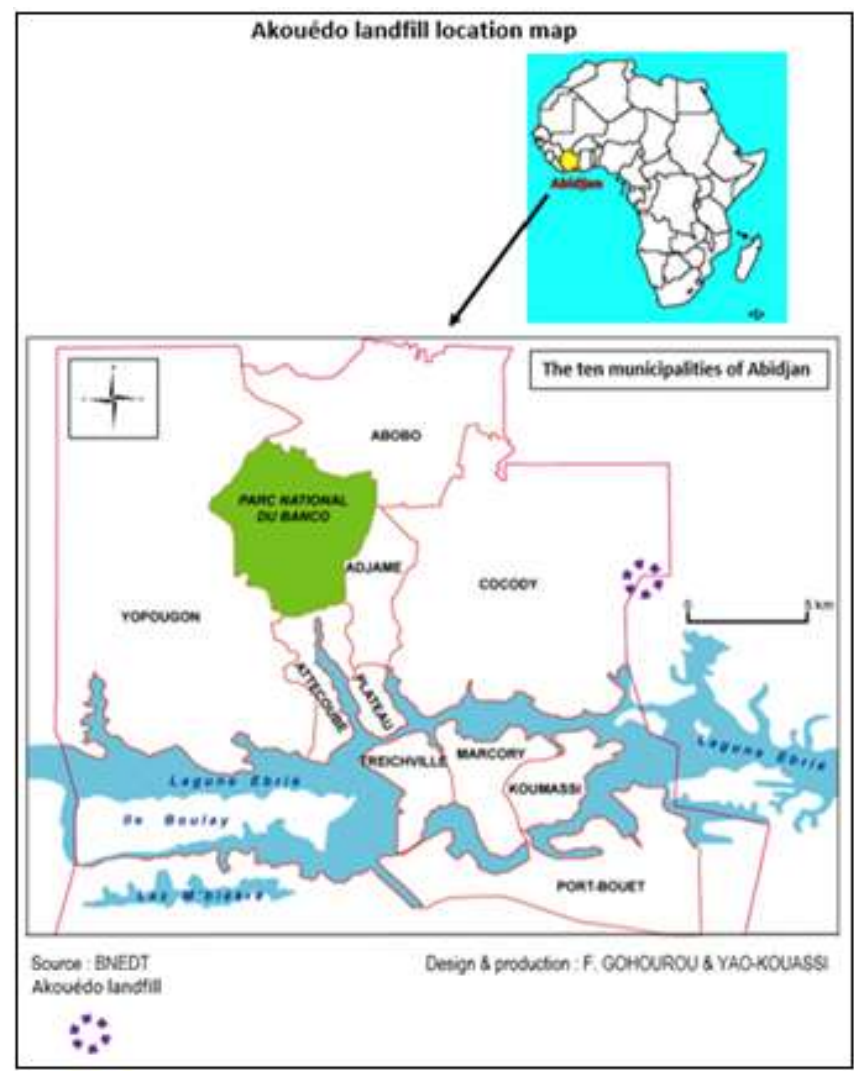

Originally, the Akouédo landfill has been installed on the outskirts of the city of Abidjan. Through the urban sprawl, some concessions are very close to landfill, which increases its vulnerability and health risks for the riparian population. A vegetable fence and sheet metal walls delimit this discharge (picture 1)

\section{Volume 6 Issue 9, September 2017}




\section{International Journal of Science and Research (IJSR) \\ ISSN (Online): 2319-7064}

Index Copernicus Value (2015): 78.96 | Impact Factor (2015): 6.391

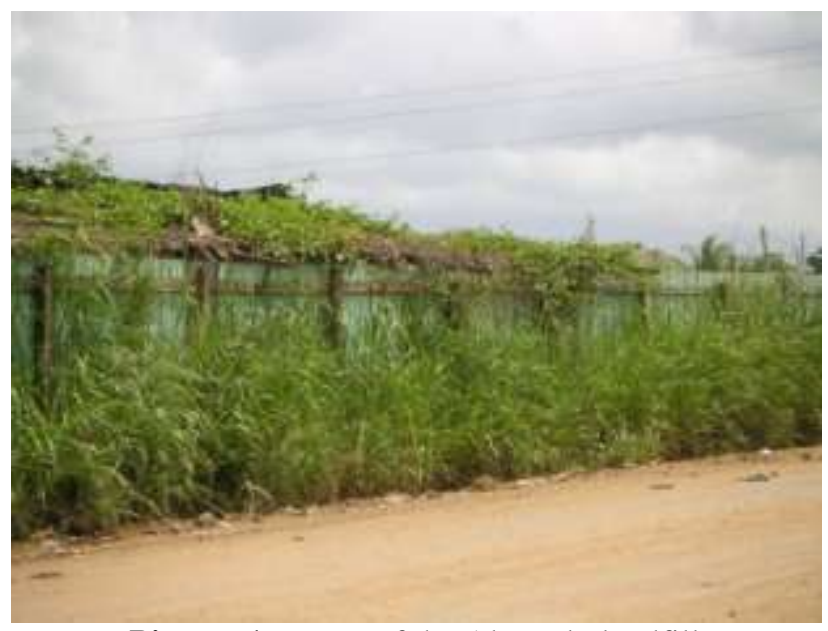

Picture 1: Fence of the Akouedo landfill

The landfill is equipped at the inlet of a Roberval type rocker and a hand-operated rocking bridge (picture 2) dating from 1965. The weighing of trucks (full and empty) are saved manually what determines the mass of the transported waste.

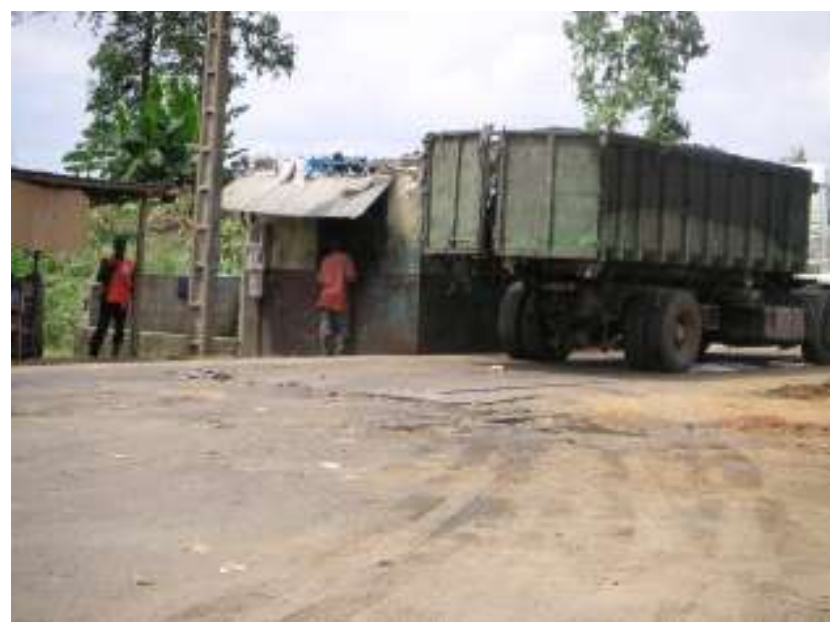

Picture 2: Weighing cabin and truck on the Weighbridge

Abidjan district that owns the land, has the administrative responsibility of the abduction and the elimination of waste. He signed a contract of subcontracting with the Pisa Impex company which is operating since November 1998.

\subsection{Operation of the Akouedo landfill}

When the waste reach the Akouédo landfill, is a quantitative control at the entrance which is done through the weighing station. This control includes essentially the origin of the waste (origin of the truck) and weighed quantity. Then, the collection vehicle is oriented towards dock where quality control (type of loading) is performed. Thus, waste are spread in layers using bulldozer. Once this is done, "Grubbers" who are children and adults of all ages are at work to recover reusable materials (picture 3). Even if all of these checks are performed, we noted that this landfill receives waste of all kinds: garbage, health, household and industrial etc.

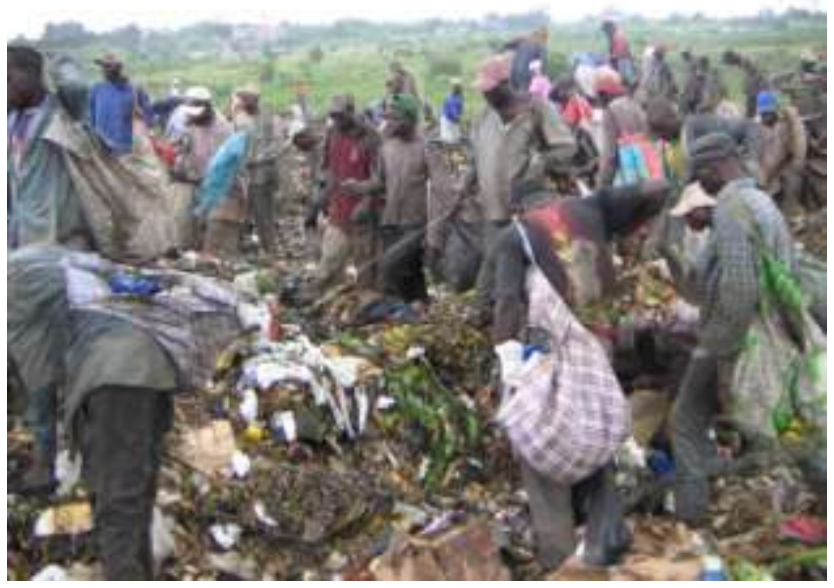

Picture 3: Grubbers operating in the Akouédo landfill

It should be noted that during the installation of the Akouédo landfill, there was no geotechnical study to guarantee the watertightness of the cuvette. However, the current operating conditions do not allow to do a controlled landfill. Road infrastructure sometimes leaves to be desired, the only access to the landfill road is asphalted. However, access to the various docks are courses in Earth (Picture 4).

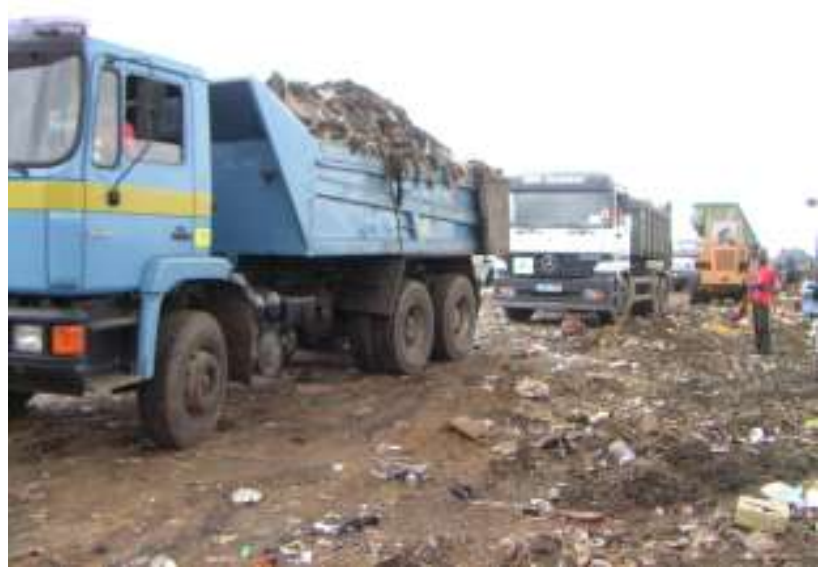

Picture 4: Trucks accessing the different docks

The pipeline system along the asphalt tracks exists for the drainage of rainwater. Inside of the landfill, the pipes are in Earth and serve as water percolation and leachate drainage. Artificial lakes exist within the landfill and have the function of purifying the leachate by a natural process to reduce its pollutant content before its evacuation to the Ebrié lagoon. Kouadio and al. (2000) noted a pollution organic and mineral waters of the ébrié lagoon located close to landfill. But the impact of the Akouedo landfill on the tablecloth in Abidjan is not yet known. Close proximity this landfill lies the field capturing called North riviera (Figure below) which allows the exploitation of groundwater for the power supply of the city of Abidjan with a high flow of $60000 \mathrm{~m} 3 /$ day according to Kouamé et al. (2006). Geology consisting essentially of sand to clay could offer a priori conditions for migration of pollutants to groundwater. 


\section{International Journal of Science and Research (IJSR) \\ ISSN (Online): 2319-7064}

Index Copernicus Value (2015): 78.96 | Impact Factor (2015): 6.391

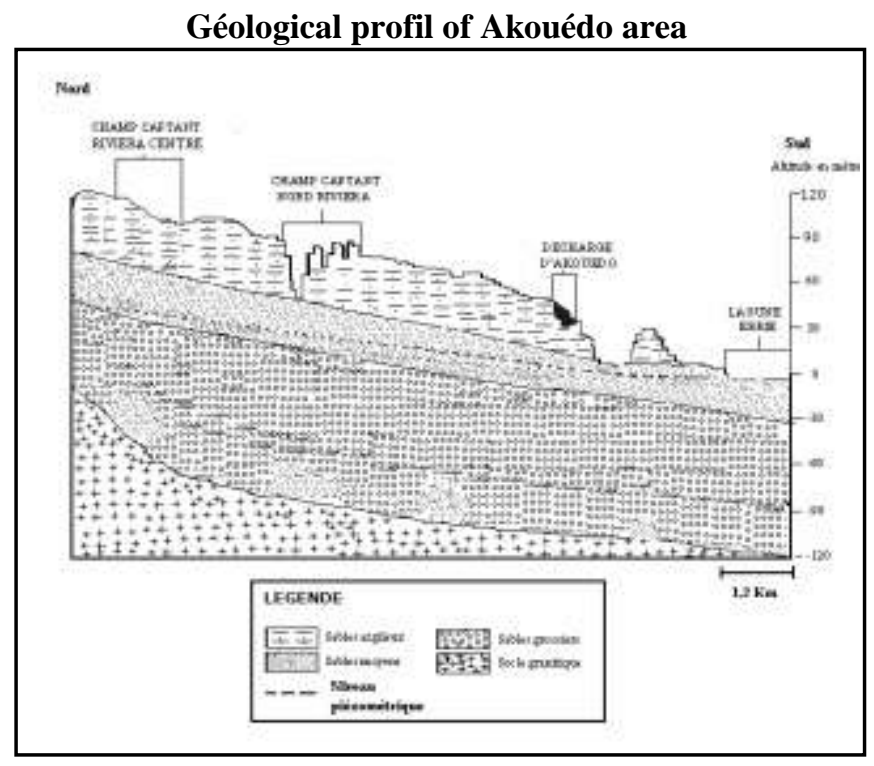

Source : Kouamé et al., 2006

\section{Results and Discussion}

\subsection{Danger of landfill}

The Akouédo landfill generates visual pollution, waste being discharged in the form of piles and spread to the bulldozer with a minimum of compaction. In addition to the flight of the dust in the nearby villages, some waste are carried by the wind. The high rate of compostable substances contained in household waste accelerates decomposition, especially in tropical environments such as the district of Abidjan where there is both the heat with a temperature range between $28^{\circ}$ $\mathrm{C}$ and $32^{\circ} \mathrm{C}$ throughout the year. with an average $2800 \mathrm{~mm}$ of rain and very high humidity.

The accumulation of waste in the landfills spreading in the atmosphere of the smells foul and pestilent. The extended stay of garbage on-site has other chemical reactions: anaerobic fermentation, which produces methane $\left(\mathrm{CH}_{4}\right)$, gas of greenhouse which contributes to the destruction of the ozone layer, and an offshoot of perceptible odour to the kilometers are residents (Yao Kouassi, 2010). The landfill presents a risk of explosion because of the mixture of air and the high concentration in the order of $5-15 \%$ methane (District of Abidjan, 2006), the proliferation of insects, rodents and birds are all vectors of propagation of diseases (malaria, yellow fever, cholera) wich are rife among the village population of Akouédo. Cremation practiced in some parts of the landfill, although that is forbidden, promotes training in the atmosphere of other gases such as oxide of nitrogen $(\mathrm{NO})$, nitrogen dioxide $\left(\mathrm{NO}_{2}\right)$, carbon monoxide (CO) and carbon dioxide $\left(\mathrm{CO}_{2}\right)$ according to Nyassogbo (2005), these gases contribute to global warming.

Visual pollution, in addition the pollution of the ground. Due to the lack of device protection, recovery of leachates and percolation waters, these cross quickly ground to reach the shallow groundwater in this area. According to management environmental and hygiene of the district of Abidjan, the groundwater would be polluted by ions $\operatorname{sodium}\left(\mathrm{Na}^{+}\right)$, potassium $\left(\mathrm{K}^{+}\right)$, ammonium $\left(\mathrm{NH}^{4+}\right)$, chloride $\left(\mathrm{Cl}^{-}\right)$, ferrous $\left(\mathrm{Fe}^{2+}\right)$ and manganese $\left(\mathrm{Mn}^{2+}\right)$ as a result of the degradation of residue urban. Indeed, the Akouédo landfill would concentrate a large proportion of heavy metals (Table below) such as lead $(\mathrm{Pb})$, zinc $(\mathrm{Zn})$, cadmium $(\mathrm{Cd})$ and chromium $(\mathrm{Cr})$ that are above the allowed values.

Concentration of the heavy metals in the soil of the Akouedo dump

\begin{tabular}{|c|c|c|}
\hline Parameters & $\begin{array}{c}\text { Concentration } \\
\text { (in ppm) }\end{array}$ & $\begin{array}{c}\text { Limit values (ppm) European } \\
\text { Directives of 1991 }\end{array}$ \\
\hline $\mathrm{Cu}$ & 369,7 & 50 à 140 \\
\hline $\mathrm{Zn}$ & 1163,7 & 150 à 300 \\
\hline $\mathrm{Pb}$ & 1500 & 50 à 300 \\
\hline $\mathrm{Cd}$ & 11,5 & 1 à 3 \\
\hline $\mathrm{Cr}$ & 125 & $\begin{array}{c}2,677 \text { [USEPA August 1990 } \\
\text { Recommendation (United States } \\
\text { Environmental Protection Agency)] }\end{array}$ \\
\hline
\end{tabular}

Source : Kouassi et al., 2006

Lead, zinc and cadmium are preferentially absorbed on the layers rich in organic matter and clay layers (Kouamé et al., 2006) constituting the ground of the Akouedo landfill. This pollution by heavy metals is more accentuated because of old paintings lead, tyres, batteries and the rubber to get to the level of the discharge. The landfill of Akouedo is located on sands and clayey sands, the Continental Terminal, essentially training the chrome is a potential risk of contamination of groundwater. With the $\mathrm{pH}$ high (more than 6) from the landfill, the predominant form of chromium would be chromium VI which is more water-soluble so more bioavailable and potentially toxic (Pichat et al., 2004).

\subsection{Impact of landfill on population}

The dangerousness of the landfill has still increased in recent years with the toxic waste scandal submitted in August 2006. The Probo Koala tanker registered in the Panama, whose crew is Russian, owned by a Greek company and chartered by the company Trafigura rejected toxic waste which are similar to petroleum products at the Akouedo landfill and in different parts of the district. According to the briefing note on toxic waste in Abidjan and who, it was rich in hydrocarbon sludge, contaminated by $\mathrm{H}_{2} \mathrm{~S}$, soda, sulphur mercaptan, Phenols, hydrocarbons (olefins, paraffins, aromatics, compounds naphtenes) and very little of organochlorines. Our results show that $99.7 \%$ of respondents had been exposed to the toxic waste with a prevalence of intoxication which was $91.1 \%$ with $60.1 \%$ of confirmed cases amongst the intoxicated. Pregnant women accounted for $36.7 \%$ of pathology in relation to intoxication with a rate of $1.3 \%$ of identified spontaneous abortions and emigration of $30 \%$ of the inhabitants of the area. This partial balance remains heavy and shows the speed and the toxicity of pollutants from these wastes. Although the poisoning of soil and water of this area is mentioned, people she was intoxicated by airway because air is the preferred chemical toxic volatile (Pignol et al., 1992). The hydrogen sulphide are very toxic by inhalation and can cause irritation of the mucous membranes and Airways to the death by poisoning of the blood, through nausea or dizziness, which was the case of several victims (8887 intoxicated and 17 dead in 2006) (Kouamé et al., 2006). "The olfactory threshold is very low $(<0,1 \mathrm{ppm})$ and the sense of smell does not increase with the concentration of the gas in the air." It can even disappear by a phenomenon of olfactory anesthesia at

\section{Volume 6 Issue 9, September 2017 www.ijsr.net}




\section{International Journal of Science and Research (IJSR) \\ ISSN (Online): 2319-7064}

Index Copernicus Value (2015): 78.96 | Impact Factor (2015): 6.391

high concentrations (> $150 \mathrm{ppm}$ ). The $\mathrm{H}_{2} \mathrm{~S}$ is a powerful inhibitor of the cytochrome oxidase mitochondrial by setting to the trivalent iron in the heme. The blocking of the respiratory chain causes hypoxia which damages the oxygeno-dependent organs. (INRS [INRS: National Research and Safety Institute], 1997). Human intoxication takes place mainly by respiratory tract, however the $\mathrm{H}_{2} \mathrm{~S}$ does not accumulate in the body, but multiple organs are affected. Acute toxicity is primarily related to the irritating properties and anoxiantes of this gas causing a quick death in a few minutes at concentrations higher than $1000 \mathrm{ppm}$ (INRS, 1997). At lower doses, conjunctivitis, a rhinitis, Dyspnea or even a delayed pulmonary edema reflect irritation of the eye and respiratory mucous membranes. These events may be accompanied by headache, nausea and loss of knowledge brief (INRS, 1997). These products also have a very strong harmfulness for the environment, which can be catastrophic if they reach the ground tables or the Middle sailor as we know that the water table is shallow at the level of the discharge with the Ébrié lagoon nearby. The presence of organochlorines, makes pollution even more serious because these pollutants persist in the environment and enter the food chain. This pollution from toxic waste came to aggravate existing pollution and continues even though it is more mediated. Despite all of the identified impacts, Akouédo landfill continues to be operated by the district and remains unique wasteway.

\subsection{The aggravated obsolescence of the Akouédo landfill}

Because of its environmental and health impact, the Akouédo landfill constantly undergoes closures related to the discontent of residents who no longer accept the proximity of the landfill with their village. The different forms of pollution and higher values of heavy metals show an environmental and health issue significant as well as the thorny problem of the treatment of the waste in Abidjan. Geochemical adsorption mechanisms that promote the vertical migration and transformation of heavy metals find themselves at the level of the ground of Akouédo which should motivate the closure of this landfill. The financial aspect and the socio-political climate contributed to the violation of the Basel convention adopted on 22 March 1989, entered into force on 5 May 1992, whose Ivory Coast joined. This convention aims to reduce the volume of trade to protect human health and the environment. In 1995, the convention was amended by the Ban Amendment, in which industrialized countries undertake not to transfer their hazardous waste in developing countries of development that many of them lack adequate for facilities treat them like the district of Abidjan. This violation of this convention with the dumping of toxic waste in the Akouédo landfill makes the discharge and dangerous surroundings. Moreover, according to the Ivorian, studies are underway by the SITRADE company for the production of electricity from biogas from the landfill and a new site for the establishment of a new landfill would be in sight. However, this new site according to some actors would have the same geological features as the Akouédo landfill and would pose the same problems related to urbanization and the water table.

\section{Conclusion}

Analysis of the dangerousness of the Akouedo dump shows that it is an important source of transfer of dangerous pollutants for man and his environment. An epidemiological study would be necessary in this area to remind and questioning the bad district waste management policy. The latter which includes several different actors, supporters at all to the dump, old and outdated technology. It would seem that the creation of a new landfill on the basis of environmental standards policy would protect the groundwater in Abidjan and would be a relief for local residents. Finally, the Akouédo landfill comes remember that creating a discharge is based on several factors: hydrogeological, hydro climate, social and economic.

\section{References}

[1] Attahi K., 2001, Abidjan, Côte d'Ivoire, pp : 17-51 In La gestion des déchets urbains: Des solutions pour l'Afrique, 2001, Direction A. Onibokun, Karthala, Paris, 250p.

[2] DISTRICT d'Abidjan., 2006, Présentation de la décharge d'Akouédo, Abidjan, 17p.

[3] INRS., 1997, Sulfure d'hydrogène. Fiche toxicologique $\mathrm{n}^{\circ} 32,6 \mathrm{p}$.

[4] Kouadio, G., Dongui, B, et Trokourey, A., 2000, Détermination de la pollution chimique des eaux de la zone de la décharge d'Akouédo (Abidjan-Côte d'Ivoire). Revue Science et Technologie - ENS-CI, Série A-01, p. 34-41.

[5] Kouamé I. K., Gone D. L., Savané I., Kouassi E. A., Koffi K., Goula B. T. A. et Diallo M., 2006, Mobilité relative des métaux lourds issus de la décharge d'Akouédo et risque de contamination de la nappe du Continental Terminal (Abidjan-Côte d'Ivoire) in Afrique Science, 02(1) (2006), pp : 39-56.

[6] Nyassogbo G. K., 2005, Accumulation d'ordures ménagères et dégradation de l'environnement urbain quelques pistes pour une viabilité environnementale dans le processus de développement africain. 11e assemblée générale du CODESRIA Maputo, Mozambique, 19p.

[7] Pichard A., Bisson M., Diderich R., Houeix N., Hulot C., Lacroix G., Lefevre J.P., Leveque S., Magaud H., Morin A., Rose M. et Pepin G., 2004, Fiche de données toxicologiques et environnementales des substances chimiques: Chrome et ses dérivés inorganiques, INERIS-DRC-01-25590-ETSC-API/SD, $\mathrm{N}^{\circ} 00 \mathrm{df} 253,68 \mathrm{p}$.

[8] Pignol F., Regimbaud M. et Grimaldi F., 1992, L'air véhicule de facteurs pathogènes in Médecine d'Afrique Noire, pp : 189-194.

[9] Touré G., 2005, La politique de l'environnement dans les capitales africaines: Cas de la ville d'Abidjan en Côte d'Ivoire, Paris, Publibook, 295p.

[10] Yao-Kouassi Q. C., 2010, A la recherche d'une synergie pour la gestion des déchets ménagers en Côte d'Ivoire: Cas du district d'Abidjan. Thèse de géographie sociale, Université du Maine au Mans, 305p. 